\title{
On the Social Significance of Large Law Firm Practice
}

\author{
Robert A. Kagan* \\ Robert Eli Rosen**
}

In a widely publicized report, Derek Bok, President of Harvard University and former law school professor and dean, recently observed:
A nation's values and problems are mirrored in the ways in which it uses its ablest people. In Japan, a country only half our size, 30 percent more engineers graduate each year than in all the United States. But Japan boasts a total of less than 15,000 lawyers, while American universities graduate 35,000 every year. It would be hard to claim that these differences have no practical consequences. As the Japanese put it, "Engineers make the pie grow larger; lawyers only decide how to carve it up."1

Although Bok was not speaking about any particular type of lawyer, the question he raises about the "way in which [a nation] uses its ablest people" seems especially relevant with respect to large corporate law firms. In 1983, 183 law firms in the United States employed more than 100 lawyers, as compared with 79 in 1978; 50 firms had more than 200 attorneys, and 14 had more than $300 .^{2}$ Paying an average starting salary of about $\$ 36,000$ $(\$ 43,000$ in New York City), each year these concentrations of high-powered lawyers hire scores of the brightest, best-educated, and most energetic young people this nation produces. Bok im-

* Professor of Political Science, University of California, Berkeley. A.B., Harvard University, 1959; LL.B., Columbia University, 1962; Ph.D., Yale University, 1974.

** Assistant Professor of Law, University of Miami. B.A., 1974, J.D., Harvard University, 1979; Ph.D., University of California, Berkeley, 1984.

For helpful comments that are reflected, however imperfectly, in this article, thanks are due Robert Post, Robert Mnookin, Ed Rubin, and Michael E. Smith. We are also indebted to Mark Aaronson, Paul Mishkin, and William K. Muir, Jr. for assistance in our survey efforts.

1. Bok, Annual Report to the Board of Overseers, Harvard University, quoted in N.Y. Times, Apr. 22, 1983, at A1, col. 1.

2. NAT'L L.J., Sept. 19, 1983, at 1. 
plies that this is not a "good thing" for the nation as a whole, and that we would be better off if these young people became engineers, entrepreneurs, bankers, government economic planners, high school principals, or political leaders.

It is difficult to find appropriate standards for assessing this contention, and harder still to do anything about it. Nevertheless, the question of how a nation's "ablest people" are deployed is surely an important and interesting one. At a minimum, it provides a useful normative starting point for exploring the social significance of large law firms.

At the outset, one can easily imagine a number of retorts to Bok's critique. For example, many of the young men and women who go to Harvard and Stanford law schools might not have the aptitude for a brilliant career in electrical engineering, and it is not clear that American industry suffers from a shortage of engineers. ${ }^{3}$ More fundamentally, entrepreneurs and corporate managers, people who are directly involved in "expanding the pie," seem to believe that paying huge fees to large law firms actually helps them in that task. By the test of the marketplace, therefore, large firm lawyering contributes to "economic efficiency."

Moreover, the Japanese saying quoted by Bok treats "carving up the pie" far too disparagingly. Formulating, refining, and implementing norms of distributive justice are immensely important social functions that are essential to political stability and necessary for economic growth. ${ }^{4}$ In terms of social function, large law firms can be described as agents of public control over large corporations. By advising businessmen how to "stay out of trouble with the law" or how to avoid costly litigation, they help implement political judgments concerning responsible and fair business practices. By serving as negotiators for corporations in

3. Japanese business firms and government agencies employ many legally educated experts who have not taken or passed licensing examinations and hence are omitted from the official count of lawyers.

4. Ronald Gilson has responded to Bok:

The greater the assurance that the piece of the pie the investor receives will be the same size as he expects, the greater the likelihood that there will be funds for the baker to bake pies, and the larger the number and size of pies that will be baked. In a world with positive information and transaction costs, developing transactional structures that reduce uncertainty concerning pie division results in more and larger pies. And business lawyers who design those structures create value.

Gilson, Value Creation by Business Lawyers: Legal Skills and Asset Pricing, 94 YALE L.J. 239, 312-13 (1984). 
disputes with governments and other business organizations, corporate lawyers often promote resource-saving compromises. By channeling disputes into the courts, law firms help ensure that these and future controversies will be resolved according to publicly stated legal principles.

In Japan, disputes are resolved by quiet bargaining among business and government elites. Ours is a more open, individualistic, nondeferential, and principled society where organizations and groups are quick to use political and judicial processes to enforce their claims. Large firms of lawyers do not cause this conflict, and, if anything, their painstakingly drafted agreements and precautionary advice make the struggle more orderly and rational.

At this level of generality, the rebuttal of President Bok's indictment seems persuasive: If large corporate law firms suddenly ceased to exist, our society would quickly reinvent them. But Bok's comments cut a bit deeper. He might agree that large law firms are essential to business managers, and that their growth can be explained as a concomitant of public efforts to subject business behavior to more complex and intrusive laws, regulations, and liabilities. Perhaps corporate law firms basically facilitate these efforts. But in the language of social function, virtually every job that somebody is willing to pay for seems "functional." Corporations find it necessary to spend a great deal of money on a great number of things. They hire security guards, accountants, janitorial companies, groundskeepers, advertising agencies, pension plan designers, architects, toxicologists, alcohol abuse counselors, environmental consultants, and dieticians. All of these services, and scores of others, pass the test of the market, and can be described in terms of a high-sounding, essential social function, such as "providing security," "enhancing communication," "maintaining health," or "enhancing aesthetic values."

The criticism implicit in Bok's comments, therefore, goes beyond the test of the marketplace and general functional analysis. It looks toward some unarticulated overriding standards for judging our institutions. For example, if many of our brightest college graduates were taking jobs in consulting firms that specialized in controlling employee theft or reducing employee drug abuse, they would undoubtedly be doing something socially useful. But one might conclude that something was deeply troublesome about the institutions of a society that had to treat those 
essentially defensive functions as the highest priority, especially if the best minds in comparable societies were engaged in creating new and more efficient productive processes or more humane and efficient social welfare programs. Thus Bok, like many others, was asking whether something is amiss in our modes of governance if corporations feel compelled to surround themselves with phalanxes of highly paid attorneys, who scrutinize their every transaction, and conduct their relations with the agencies of government. Others might respond that all this lawyering is a sign of a healthy society, where corporations quite properly are subject to lawsuits when they cause harm, and where they in turn can pressure courts, regulators, and tax officials to take economic realities into account in applying the law.

Without attempting to resolve this issue, we can restate Bok's concern in another way. If we take as given our peculiar set of lawyer-breeding institutions and attitudes, and assume that business corporations are justified on economic grounds in supporting huge law firms, we still might compare the social worth of lawyering with all the other occupations that businesses (and households and governments) find it worthwhile to support. ${ }^{5}$ If large firm lawyers do, in some sense, help the economic pie grow larger, so do bankers, corporate managers and staffs, entrepreneurs, financial planners, export brokers, and cost accountants. If large firm lawyers influence the distribution of resources, there surely are many people in government service, advocacy groups, and perhaps the media who are more directly and fundamentally involved in that process. If we assume that the young men and women who succeed in getting through elite law schools and into large law firms would also rise to the top in other occupations, is there any way to assess whether we, as a society, would be better off if instead they became police department administrators, legislative assistants, policy analysts, investment bankers, or plant managers? To phrase the issue another way, if you were Czar of

5. Of course, some people may believe that working to advance the interests of big corporations is by definition socially harmful or antithetical to the interests of "the people." Such a position, however, forecloses any meaningful inquiry. For the purposes of this essay, therefore, let us simply stipulate that the corporate clients of large law firms, for better or worse, are in fact the central economic institutions of our society. It is on their productivity, efficiency, reliability, and degree of social responsibility that our wellbeing largely depends. Working to advance their performance in these respects, which corporate lawyers in theory might do, would therefore be socially beneficial. Reducing corporate performance in these respects, which corporate lawyers also might do, theoretically could be socially harmful. 
Personnel, charged with directing the most talented young people to the positions where they would make the greatest contribution to social utility, what priority would you give to corporate law firm practice?

The happy fact that we have no Czar of Personnel, and the further fact, happy or not, that corporate law practice includes such a bewildering variety of legal tasks, does not make the question undiscussible. It is, after all, the kind of question college students and law students ask themselves, whether or not they have heard of Derek Bok. ${ }^{6}$ In this essay, we try to provide a way of thinking about the social utility of corporate law practice, ${ }^{7}$ and

6. As a twenty-year-old, Charles William Eliot, later to become one of Bok's predecessors in the Harvard presidency, wrote to a friend:

What a tremendous question it is-what shall I be? When a man answers that question he not only determines his sphere of usefulness in this world, he also determines in what direction his own mind shall be developed. The different professions are not different roads converging to the same end; they are different roads, which starting from the same point diverge forever, for all we know .... Now it seems to me that very few young men have the requisite data for an intelligent decision of the above question.

B. Bledstein, The Culture of Professionalism: The Middle Class and the DevelopMENT OF Higher EduCATION IN AMERICA 159-60 (1976) (quoting letter from C.W. Eliot to Theodore Tebbets, Jan. 29, 1854), (available at Harvard University Archives, C.W. Eliot MSS, Box 440).

We do not mean to imply that students who seek a legal career or law school graduates who go to work for large law firms do so primarily because they feel it would maximize their potential "sphere of usefulness in this world." Their actual reasons may relate principally to their hopes for financial security and social status, or to a psychological attraction to the intense competition that characterizes many spheres of legal practice. But we suspect that a yen for influence on powerful actors and events, achieved in a way consistent with public values such as legality and probity, often plays a significant role in such choices. Whatever the motivations of prospective lawyers, we believe their career choices may be influenced by a fuller understanding of the social significance of large firm law practice.

7. In this essay, we use the terms "large law firms" and "corporate law firms" interchangeably to refer to any firm whose clients are predominantly medium- or large-sized corporations. Many such firms, of course, have fewer than 100 lawyers and some have fewer than 30, and thus cannot be considered "large" by present day standards. Large corporate law firms, by virtue of their prominence and tendency to pay high salaries and recruit top-of-the-class graduates from elite law schools, are the primary focus of the questions we pose. But in discussing social functions or legal tasks, our comments apply to all corporate lawyers, and we are not suggesting that the size of large firms per se is a critical variable.

We also recognize that large law firms are often entry points for lawyers whose careers take them into other jobs, such as in-house corporate law departments, corporate management, and public service. Some large firm lawyers combine their careers with periodic stretches of governmental service, or are appointed to temporary government commissions, bar association committees concerned with law reform, and boards of civic and charitable organizations. We know of no evidence that systematically com- 
advance some hypotheses about how it may be changing.

\section{Four Images of Corporate Legal Practice}

What is it that corporate lawyers actually do? They often respond in terms of the legal specialties around which large firms are organized: litigation, antitrust, "deals," securities, tax, or real estate. The tasks they perform are often described in such terms as drafting, negotiating, advising, or devising litigation strategy. 8 These "legal" categories, however, tell us little about the social significance of large firm law practice. It seems more helpful to describe lawyers' work in terms of the impact it has on the policies and practices of their corporate clients, whose actions deeply affect our national well-being. Unfortunately, we have encountered no useful typology of outside lawyers' functions, cast in terms of their contribution to corporate activity. Nor have we encountered any data reflecting a frequency distribution of the specific tasks they perform. We will proceed, therefore, by outlining four contrasting and necessarily quite general "images" of the corporate lawyer's role.

One dimension of these images concerns the degree of influence the lawyer has on corporate decisions. The second dimension concerns the degree to which the lawyer's autonomous judgment matters: Do existing corporate directives and objectives closely constrain the lawyer's work, or does the lawyer draw upon other sources-rules and principles of law, conceptions of public policy or political realities, the lawyer's own business sense-in giving advice or taking legal action? Combining these dimensions into a matrix yields the following typology:

\section{Images of the Corporate Lawyer's Role}

\begin{tabular}{lccc} 
Corporate Lawyer as: & $\begin{array}{c}\text { Degree of } \\
\text { Autonomous } \\
\text { Judgment }\end{array}$ & $\begin{array}{c}\text { Degree of } \\
\text { Influence on } \\
\text { Corporate Decisions }\end{array}$ \\
\cline { 2 - 2 } $\begin{array}{lcc}\text { Independent Counselor } \\
\text { Conduit }\end{array}$ & $\begin{array}{c}\text { High } \\
\text { Insurer }\end{array}$ & & $\begin{array}{c}\text { High } \\
\text { Low }\end{array}$ \\
Manipulator & Low to High & & Low High \\
Low & & High
\end{tabular}

pares large corporate firm lawyers to other kinds of lawyers in these respects. Our focus in this essay is not on large law firms as routes or bases for other kinds of jobs and activities, but on large firm lawyering.

8. See E. Smigel, The Wall Street Lawyer (1964). 
The tasks performed by large law firms, we assume, fit all these images to some degree, especially since the dimensions represent continua, not fixed categories, and the images may overlap. Nevertheless, the social significance of corporate law practice can be viewed in terms of the frequency with which practitioners approximate any one of the images.

\section{A. The Dominant Image: Large Firm Lawyers as Infuential and Independent Counselors}

When a Czar of Personnel would think about matching a nation's talent to appropriate jobs, or when a bright and ambitious student thinks about choosing a career, he or she would consider not only the general social function of the particular job, but also the specific tasks involved. The degree and scope of discretion, influence, responsibility, and independent judgment entailed would be of primary importance. Imagine posing this question to a top-of-the-class college student who is planning to attend law school: "Whatever your present thoughts about 'public interest law,' most law school graduates end up serving business corporations. Why would you want to be an outside lawyer to a corporation rather than, say, corporate chief of security? Both jobs defend corporate assets against those who would steal them or reduce their value. The lawyer simply defends assets from those who would diminish them by breaking agreements, bringing lawsuits against the company, taxing it, or imposing regulatory requirements that are arguably not warranted by law. The security director tries to implement strategies that help defend corporate property from those who would steal, embezzle, or vandalize it. Of course, starting salary and working conditions in a corporate law firm would be far superior to those in a corporate security department, and the intellectual challenge of working with law books and documents and other lawyers may be more appealing than the intellectual challenge of detecting and anticipating employee malfeasance (although we don't quite see why). The attorney has more job security. And it's undoubtedly true that being a lawyer at a comfortably appointed Park Avenue law firm entails more social status than being a deputy director of corporate security at Bethlehem Steel, or even at IBM. But putting aside those considerations of salary, working conditions, and status, would one job be preferable to the other on grounds of personal satisfaction or contribution to the common weal?" 


\section{Influence.}

One answer might be that the choices made by the corporation's lawyers require more judgment and provide greater opportunities for responsible influence than the tasks of the chief of security. Although the chief of security surely must exercise a good deal of discretion, imagination, and supervisory responsibility, it is a partner in a major corporation's law firm who sits on the board of directors, not the security director. Why? First, the lawyer's work, if done badly, will usually involve greater potential loss; the difference between the amounts saved by an excellent and by an ordinary corporate security chief probably is relatively small.

Second, although details may change, the corporate security director can be viewed as carrying out established and relatively stable corporate policy. The corporation's outside counsel, on the other hand, often must anticipate and defend against nonroutine, unexpected, or major threats to the corporation's finances-for example, the antitrust suit that threatens the corporation's distribution system, the imminent bankruptcy of a major customer or supplier, or the legislative proposal that threatens to increase drastically the cost of doing business. While these problems may be routine for the lawyer, in the sense that an antitrust lawyer faces them all the time, they are not routine for the corporation. The outside lawyer must bring together legal and business concerns in crisis situations, and therefore, the lawyer's advice is likely to be highly influential.

Third, the lawyer's influence rests on the arcane and inaccessible nature of his statements and judgments about the law. Certainly, how the security director performs his job has a significant impact on the character of the corporation's workplace; an excessively totalitarian security regime wastes money and alienates personnel. But corrections to his excesses emerge through regular corporate channels. In contrast, corporate executives often lack the expertise to assess the quality of a lawyer's advice or actions, or to evaluate the "real" necessity for the measures he suggests. In sum, with more at stake, in less certain circumstances, the corporation's law firm bears greater responsibility, and exercises greater influence. The lawyer not only devises and implements strategies to carry out established policies but also helps the corporation develop policies and cope with a broader range of uncertainties and threats. 
This image of the corporate lawyer-the influential counselor on political, economic, and legal issues of great moment, the advisor who sees the hidden threat around the corner, the emergency negotiator or litigator deflecting potentially mortal blows-is the portrait painted in James B. Stewart's The Partners. ${ }^{9}$ The Partners is the most detailed published description of largescale lawyering. In somewhat breathless prose, Stewart portrays the following exploits:

Incredibly hard working lawyers at Cravath, Swaine \& Moore save IBM from the Antitrust Division's ill-advised attempt to dismember it, and from a prejudiced U.S. District Court judge inclined to so rule.

Aggressive litigators at Chicago's Kirkland \& Ellis conceive and gather the evidence for a novel antitrust counterclaim against Westinghouse's uranium suppliers; this is crucial in helping Westinghouse withstand a mammoth lawsuit by its utility company customers for breach of an unwisely formulated uranium supply contract.

Tireless negotiation by Debevoise \& Plimpton lawyers pull together scores of nervous bankers whose cooperation is a prerequisite for the government-backed refinancing and loan guarantee that saved Chrysler.

Canny understanding of financial markets and clever drafting by lawyers from San Francisco's Pillsbury, Madison \& Sutro steer a public offering by an innovative genetic engineering company through the legal minefield of securities law.

Sullivan \& Cromwell helps Kennecott Copper Corporation expel an obstructive dissident director seeking to gain control of Kennecott, by launching a "hostile takeover" campaign directed at the dissident director's company and by brilliantly preempting his legal defense.

Overall, The Partners portrays large firm lawyers as having an independent impact on major events. In some cases, they are legal strategists and litigators of such imaginativeness and thoroughness that they bail corporate management out of difficult predicaments that the managers themselves, or that less well-organized and high-powered law firms, would be unable to handle as effectively. In other cases, the lawyers are shown as the corporation's policymakers and negotiators in emergency or crisis situations. They fill a managerial void with the uncommitted resources of intellect, energy, and experience that only large law firms have on tap, thus bolstering the corporation's adaptive capacities.

9. J. Stewart, The Partners: Inside America's Most Powerful Law Firms (1983). 
The large firm lawyer is also frequently portrayed as having an independent influence on the law. In The Other Government, for example, Mark Green asserts that "Washington lawyers are among the most powerful people in the country," 10 not mere advocates of their corporate clients" positions but "[e]arthshakers and lawmakers" who confuse regulatory bureaucrats and reshape the law to favor corporate rather than public interests. ${ }^{11}$ Green assumes that the positions Washington lawyers advocate are invariably contrary to the public interest. A more skeptical view of regulation might lead others to conclude that the arguments of persuasive corporate attorneys play a valuable role by keeping regulatory officials and judges well-informed about the technical impact of proposed regulations and legal decisions, and by insisting that they give adequate attention to considerations of economic efficiency. From this standpoint, corporate lawyers' influence on legal decisionmakers might provide an important protection against shortsighted, biased, uninformed, or overly legalistic regulation. ${ }^{12}$

Whether one considers corporate lawyers' influence on regulatory and common law as generally good, bad, or variable, the crucial assumption underlying these views-one which makes a large law firm career attractive to many ambitious law studentsis that corporate lawyers do have special and frequent opportunities to have a significant influence on the development of law and public policy. Large firms have special advantages in influencing the substance and the language of legal decisions: They have excellent personal contacts and access, and the organizational capacity to monitor and anticipate all relevant governmental actions and legal developments. They also provide lawyers with the opportunity to specialize, which gives rise to in-depth expertise and the ability to detect weaknesses in adversaries' positions. They have the resources of wealth and manpower that provide the capacity to gather and marshal huge amounts of information, to conduct high-intensity research and pretrial discovery, and to write articulate briefs and letters on short notice. Finally, large firms lawyers often have above-average powers of argument and

10. M. Green, The Other Government: The Unseen Power of Washington LAWYERS 4 (1975).

11. Id. at 9 .

12. On the risks and causes of economically unreasonable regulatory decisions by agencies and courts, see E. Bardach \& R. Kagan, GoIng by the Book: The Problem of REGULATORY UNREASONABLENESS (1982). 
persuasion honed by close association with intelligent, experienced, and articulate partners.

\section{Autonomous Judgment.}

In referring to corporate lawyers as having an independent influence on events, we use the word "independent" in a causal sense: Outcomes are not predetermined by law, corporate policy, and circumstances. The lawyer's judgment and skill matter. Bad thinking, sloppy argumentation, and inadequate preparation would produce a different outcome.

Another meaning of "independence," which we will designate "autonomy," concerns intellectual or moral independence. It is often said that outstanding corporate lawyers are valued by corporate managers not merely for their legal expertise but for their business judgment. Because the outside counsel does not work in or exclusively for a single corporation, he is less likely to be caught up in current management's way of seeing things or habits of deference to the chief executive officer. The lawyer can bring his own perspectives, analytical capacities, and experiences to bear in assessing corporate investment plans, proposed deals, and marketing strategies.

The corporate lawyer's judgment, in this dominant image, is autonomous from that of their corporate clients in another sense. Suppose, in a variant of our earlier question, you were to ask a bright college senior why he or she would want to go to law school and work for a business executive, rather than directly seeking a job in a business and ultimately trying to be that executive. A frequent answer, we suspect, would invoke a sense that lawyering rests on a higher ethical plane. A career in "the law" involves not only helping clients make money but also furthering "justice" or "legality."13

The corporate lawyer, in this image, attends to standards that

13. Part of the self-image of the American legal profession has been that lawyers would serve as a sort of American aristocracy, mediating between the threats to the common weal posed on one side by economically irresponsible, popularly elected politicians, and on the other side by socially irresponsible capitalists. Thus the profession, and particularly the large law firm, generally has attracted children of businessmen who are seeking-often with their fathers' encouragement-a "genteel," somewhat intellectual role in which they would distance themselves from, yet not entirely reject, the life of commerce, and also participate in public governance, but without descending into the rough and tumble of electoral politics. See Gordon, Introduction to Symposium on the Corporale Law Firm, 37 Stan. L. Rev. 271 (1985). 
transcend his clients' most immediate and narrow economic selfinterest. In giving advice, he refers not only to specific rules of black-letter law, but also to general principles of equity, fair dealing, and public policy in dealing with inchoate or potential legal problems. ${ }^{14}$ By advising businesses about the legal risks, constraints, and requirements associated with proposed actions, the corporate lawyer plays a crucial role in pushing businesses toward socially responsible behavior. By advising businesses about the probabilities of losing pending or imminent lawsuits, the lawyer promotes prompt and fair settlements of disputes that emotionally involved executives might be inclined to drag out and litigate. By telling business executives how to avoid antitrust suits, civil rights suits, and regulatory prosecutions, and by insisting on knowing the truth about financial weaknesses that might affect the accuracy of representations in disclosure statements, license applications, or opinion letters signed by the law firm, the lawyer necessarily forces corporations to be more honest and to establish internal systems for ensuring compliance with the law. The corporate lawyer, from this perspective, is an autonomous agent of social control and law enforcement.

Indeed, the image of corporate lawyers as agents of social control sometimes extends beyond the role of translating existing law into actual constraints and precautions. The corporate lawyer may also serve as a more generalized conscience of the corporation. More detached and independent than a corporate chief executive's subordinates, the lawyer can feel free to warn business executives that even if proposed actions do not violate the law per se, they might nevertheless be ethically questionable or might lead to popular or political attacks, adverse reactions by customers or competitors, or intensified governmental scrutiny. As the corporation's negotiator in conflicts with government agencies and other businesses, the outside lawyer, because of the

14. Thus a former member of a 300-lawyer firm wrote:

The typical company seeks [lawyers'] advice to avoid future costly legal battles. Yet, by advising a company of the legal parameters within which it must operate, the business attorney necessarily serves as guardian of the public interest ... . What is equally important is that his advice is not limited to the "letter" of the law . . . . Ethical and public-policy elements are important components of legal precedent. Any conscientious attorney guards his client against liability (and thus the public from harm) by taking into account how a judge is likely to interpret acts not identical to situations previously adjudicated or not precisely contemplated by statute.

Hanover, Corporate Lawyers Do Public-Interest Work, Wall St. J., Feb. 23, 1984, at 28, col. 1. 
more detached position, can sometimes be a creative mediator who develops the compromise position that averts litigation or saves the deal.

Given these roles, there might be little objection, on public policy grounds, to the rush of very bright and creative young men and women into the ranks of large corporate law firms. Indeed, by combining legal, ethical, and business concerns to influence corporate processes, large law firms, viewed in terms of this image, perform a vital function in our decentralized system of legal control. Lawyers correct both corporate decisions tending to transgress public interests protected by law and serve as buffers between the state and their clients. By rendering judgment which is independent, influential, and expressive of both public and private concerns, lawyers help limit the state to its proper sphere, match local information with general policies, regularize private transactions, and prod corporate institutions toward fulfillment of public aspirations.

\section{B. Counter-Image I: Large Firm Lawyer as Conduit}

In the cases described in The Partners, the lawyers involved undoubtedly played major roles. Stewart's accounts, however, are written from the standpoint of his lawyer-informants, not of the corporate managers who hired them. Hence the lawyers appear somewhat like knights-errant, riding out to cope with various dragons, while the corporate managers huddle passively inside the castle walls hoping their pin-striped heroes will devise and implement a winning strategy. Chrysler's outside lawyers are described as flying from city to city to "negotiate," with no mention of frequent telephone calls back to corporate headquarters for consultation about what line to take or what concessions to make. There is no mention of the role IBM's inside counsel, marketing people, economists, or other executives-those who presumably knew the computer business-might have played in formulating and documenting the substantive arguments that were used to parry allegations of monopolization.

All this, of course, seems rather unrealistic. Indeed, in contrast to the image of the highly autonomous and influential lawyer-policymaker and lawyer-strategist, one might construct a counter-image of corporate lawyers as primarily client-directed technicians who merely implement the plans, agreements, and defenses conceived by corporate officers and directors. The cor- 
porations that employ large law firms, after all, are not unsophisticated. They have knowledgeable inside counsel who are more familiar with the corporation's business environment than outside lawyers, and who are also probably more familiar with most areas of law relevant to the company's operations. ${ }^{15}$ Indeed, major corporations have specialized executives charged with keeping up on developments in areas which affect company operations, such as labor law, product safety, pollution control, and consumer finance law. Corporate managers also receive advice from sophisticated investment bankers, tax accountants, and lobbying or political affairs organizations. Thus, when corporate officers contact outside counsel, usually one might expect them to know what they want, at least in general. They simply lack the legal manpower to research points of uncertainty in the law, conduct litigation, or draft detailed documents. Indeed, Heinz and Laumann's detailed study of Chicago lawyers indicates that lawyers who specialize in corporate and securities work have less autonomy than lawyers whose clients are small companies and individuals. ${ }^{16}$ The larger and more sophisticated the client, the less one would expect the lawyer's input to matter in shaping the client's decisions and strategies.

Clearly, large law firm lawyers are the spokesmen of the powerful. They are often "present at the creation" when decisions are made and deals are struck. They experience a sense of excitement from participating in large events and negotiating with governments. ${ }^{17}$ But that does not mean, as Mark Green implies

15. For a discussion of the increasing role played by inside counsel, see Chayes \& Chayes, Corporate Counsel and the Elite Law Firm, 37 STAN. L. REv. 277 (1985).

16. J. Heinz \& E. Laumann, Chicago Lawyers: The Social. Structure of the Bar (1983). See also Heinz, The Power of Lawyers, 17 GA. L. REv. 891 (1983).

17. Thus, one corporate firm partner based in Paris (who read a draft of this article), when asked to describe matters he had recently worked on, responded:

During the last two and a half years, I have spent considerable time (i) negotiating with the French Government the nationalization of the French interests of (two large American corporations) and (ii) advising a French client caught between the U.S. law forbidding the export of technology and its contractual obligation to the Soviet Union in the trans-Siberian pipeline dispute . . . These projects are challenging per se, and the opportunity to participate in this work is, in my view, the main source of attraction for young lawyers to large firms.

Unfortunately, this brief description does not allow us to determine whether the attorney acted primarily as an intelligent conduit of facts and arguments between government officials and corporate client, or as creator of new arguments or compromise positions. 
in The Other Government, ${ }^{18}$ that the lawyers themselves are independently powerful or influential in shaping results. A counterimage would view them primarily as conduits of their clients' views to outsiders, or in the pejorative vernacular, as "mouthpieces." They also may serve as conduits to corporate decisionmakers of legal threats posed by government or private parties but leave ultimate judgments about how to respond to the corporate managers.

Green's contention that Washington lawyers (and by implication other large firm corporate lawyers) constitute an "other government" is premised on a vision of law, courts, and government officials as extremely malleable in the hands of clever lawyers. A competing view, while conceding that "the law" is not always clear, would emphasize that it is not infinitely malleable and that most regulatory agencies, judges, and competing private interests are quite capable of making intelligent independent decisions. As Daniel Polsby points out, the events that Green recounts suggest more "losses" than "successes" for Washington lawyers, and most Washington lawyering actually consists of straightforward, factually detailed presentation of applications or requests for exceptions based on the law and regulations as written. ${ }^{19}$ The style is the lawyers', but the content, for the most part, is dictated by relatively clear government policy or law, and by the factual details and problems brought forth by corporate management. The corporate lawyer may reshape his client's arguments and factual submissions into the forms and categories of the particular bureaucracy or of judicial precedent, but the job is primarily translation, not invention or independent influence.

In sum, working at the interface between sophisticated government agencies and major corporations, lawyers help rationalize communication, but the outcomes of those interactions, in the lawyer-as-conduit image, are dictated more by the policies, resources, and wills of government officials and corporate managers than by the corporations' lawyers.

This does not mean that the large law firms don't have special skills or that they don't exercise any judgment. In this low-independence counter-image, however, they are more like the architects hired by the corporation to design a new "no frills" factory.

18. M. GREEN, supra note 10 .

19. Polsby, Book Review, 74 Mrch. L. Rev. 148 (1975) (reviewing M. GreEN, supra note 10 ). 
The lawyers, like the architects, use professional knowledge and imagination, as well as-concentrated, specialized manpower. However, they chiefly decide how to achieve specific ends already decided upon by corporate management, within clearly designated technical and financial constraints.

This image of corporate lawyer-as-conduit reduces the range of the lawyers' social control function. It is true that corporate lawyers often prevent potentially illegal corporate action by pointing out legal or regulatory liabilities. Lawyers may also induce corporations to settle by informing managers that claims against the company would most likely be vindicated in court. Thus, the lawyer-as-conduit does have an influence on corporate action, as in the dominant image. But the conduit image suggests that lawyers are likely to succeed in "directing" or "restraining" corporate action only when the corporation's legal "exposure" is relatively clear. In these instances, the lawyer transmits settled legal policies made by legislatures, courts, and administrative agencies, but is not a creative agent of social control. The outside law firm, if used in such cases at all, usually is employed only to provide comforting (and responsibility-diffusing) verification of what inside corporate managers or lawyers already know or sense.

Indeed, the outside law firm is most likely to be consulted when the legal consequences of particular actions are uncertain. But in such cases, the outside firm's answer is likely to be "it depends," leaving the ultimate judgment to corporate managers. Outside lawyers may also be asked to help the client react to legal uncertainty by suggesting methods of rephrasing agreements or disclosure statements, or by tinkering with the company's proposed course of conduct, in order to minimize the chances of legal action or damages. Rather than social control, corporate lawyers will be engaged in constructing "legal insurance" arrangements to protect the course of action that the company will pursue anyway. We will discuss this function further in the next section. From this perspective, corporate law firms will rarely stop clients in their tracks by invoking authoritative legal rules or principles. Rarer still are instances in which the law firms go beyond the law and act as general "consciences of the corporation," urging corporate managers to attend to social policy considerations, or to emergent norms of social responsibility. Unlike some corporate staff specialists, such as occupational 
safety engineers or toxicologists, the corporation's lawyer will rarely try to change corporate policies and decisionmaking techniques in order to advance certain regulatory values; instead, the lawyer is more likely to respond reactively to corporate requests for specific advice about the law, or to handle specific litigational tasks.

In this counter-image of lawyer-as-conduit, therefore, outcomes are forged primarily by the clash of interests of powerful corporations and government agencies. The judgment of corporate executives or of governmental officials will count far more than the judgment and arguments of the corporation's outside attorneys. Lawyers may help in the negotiations, and any lack of skill on their part can sometimes affect outcomes, but in their relations to their employers, they are more like a President's ambassador than like a strong Secretary of State who shapes policy and defines acceptable concessions alone.

\section{Counter-Image II: Large Firm Lawyer as Insurer}

Corporate lawyers may move beyond the essentially reportorial or executive role of conduit into the task of constructing "legal insurance" arrangements to protect the company. In most of the work on "deals" that forms such a large part of corporate practice, for example, the large firm lawyers essentially fill in the details of agreements made for business reasons by executives. The contracts and debentures that the corporate lawyers draft might be thought of as elaborately tailored insurance policies, listing the various adverse contingencies that conceivably might arise should the deal "go wrong," defining these events precisely, specifying security arrangements, and stipulating what expediting or remedial actions should be taken and by whom. Negotiating and writing these "insurance" provisions requires a good deal of experience, knowledge, intelligence, and care. In the event things do go wrong, seemingly small and technical mistakes in drafting can determine who must bear losses that can amount to millions of dollars. Hence, corporations find it worthwhile to pay their lawyers well for such services, just as they find it worthwhile to pay significant fees for liability and casualty insurance. The fact remains, however, that most of the contingencies that the corporate lawyers worry about are remote possibilities, quite secondary to the likely flow of events, and ninety percent of these elaborately drafted provisions are proba- 
bly never referred to again after the agreement is signed. If the architect does a bad job, the building may fall down or its occupants may suffer tangible inconvenience or discomfort; if the corporate lawyer-as-insurer does a bad job, usually it will not matter, unless business for at least one party to the agreement turns very bad. We are not suggesting that it isn't important to insure against calamities. Our point is that in this counter-image, corporate lawyers are more likely to spend their time writing insurance provisions against calamities that usually do not occur than constructively shaping the course of events.

The lawyer-as-insurer employs more autonomous judgment than the lawyer-as-conduit. This role involves addressing problems and considerations, both legal and financial, that might be neglected by corporate managers, whose eyes are fixed on the short term and on the apparently probable outcome. Unlike the lawyer-as-conduit, who is more of a legal technician or sophisticated messenger, the insurance man makes combined legal-business judgments and sometimes influential recommendations about how a transaction should be structured, which may in turn affect the price and viability of potential deals. ${ }^{20}$ But compared to the counselor in the dominant image, who also makes combined legal-business judgments and recommendations, the lawyer-as-insurer usually has far less "influence," simply because the insurer's influence often is exerted on more peripheral, less fateful matters. The distinction obviously is one of degree. Yet the frequency with which corporate counsel's recommendations are concerned with more remote and less central contingencies is reflected in the commonly referred to statement of corporate managers making an important decision or agreement: "Let's keep the lawyers out of this as long as we can."

This hypothesis - that corporate lawyers spend much of their

20. For example, one large firm lawyer who read a draft of this paper identified his work as falling "primarily in the municipal bond field, giving legality and tax opinions to issuers and purchasers of tax exempt bonds." He stated that "most of my work is in the area of 'insurance man,' especially in disclosure documents and security instruments." While often not very creative, he argued, "this administrative labor . . . helps towns and cities raise money for necessary projects." Similarly, a New York lawyer argued that his work as "insurance man" often helps "reduce the risk premium associated with the transaction . . . by substituting legal protection. Often such drafting makes possible transactions that would otherwise not be viable."

For a persuasive demonstration of the ways in which business lawyers reduce uncertainties and thereby help markets operate more efficiently with respect to corporate acquistions, see Gilson, supra note 4 . 
time preparing insurance arrangements for remote contingencies-might also be suggested for other spheres of large firm practice. Although The Partners tries to emphasize the large law firms' contribution in shaping events, it also suggests the prevalence of the insurer role. For example, teams of Debevoise, Plimpton lawyers, in Stewart's account, slaved over a detailed disclosure statement concerning Chrysler's condition even though the obviously risky decision of banks and Chrysler dealers to lend Chrysler money was based on necessity or loyalty and not on the particular phrasing of Chrysler's financial prospects settled on by the lawyers. The lawyers' job was to draft language that would provide insurance against lawsuits in the event that Chrysler defaulted and some lenders tried to claim that they had been deceived. Similarly, Stewart quotes a top securities partner at Pillsbury, Madison and Sutro as saying:

I wrote every prospectus for Occidental Petroleum from 1960 to 1969 , when I had to resign as counsel due to a conflict of interest. . . . Not one suit was ever brought. After I resigned, suits were brought on every prospectus the company offered. Why? Not because I was a better lawyer. In 1969, Libya nationalized Occidental's oil wells and its stock plunged. ${ }^{21}$

Even in litigation, where law firms are engaged in fighting actual battles rather than guarding against remote contingencies, much of the actual work has an insurance-like flavor: Associates spend countless hours doing legal or factual research that only might be referred to in trial or settlement negotiations. The ideal of exhaustive "preparation," of "leaving no stones unturned"even though it may represent a rational strategy for balancing large risks against an investment in prevention-means that much of the work of law firm litigators is the turning of stones which conceal nothing that will ever be used.

The implication of the large firm lawyer-as-insurer image is that much of the work will be defensive and ultimately only remotely important, rather than constructive and event-shaping. Hours will be spent on litigation that to corporate clients represents only rear-guard actions, or tactical feints in a war whose outcomes ultimately will be shaped by larger economic, financial, and political developments, and shifts in bargaining power.

21. J. STEWART, supra note 9 , at 151 . 


\section{Counter-Image III: Corporate Lawyer as Manipulator}

In the dominant image, the lawyer maintains a certain moral distance from his client. Regardless of differences among the corporate bar concerning the circumstances under which a lawyer must withdraw from representation, or a lawyer's duty to "blow the whistle" on wrongdoing by clients, both sides in the debate stress the lawyer's obligation during the representation to advise against illegal activity. Lawyers concerned about ethics worry whether their client "really" is the particular corporate manager who confides in them, or "the corporation" itself. The distinction implies that the lawyer's professional obligation may require him to differ with current management when he thinks it is acting illegally. Moreover, the influential and independent counselor would advise against and work to defeat corporate plans or tactics that, even if not clearly illegal, strike him as illadvised or violative of inchoate, emerging norms of socially responsible business behavior. ${ }^{22}$

It is not difficult, however, to imagine corporate lawyers failing to meet this standard, at least on occasion. To visualize a distinct counter-image, consider a case in which the president of a sizable privately held corporation, justifiably accused by a minority stockholder of self-dealing, instructs the corporation's attorney to "get him out of the way." The attorney raises no objections and proceeds to do so, using entirely "legal" methods. ${ }^{23} \mathrm{He}$ drafts denials of the stockholder's charges, using plausible but essentially specious arguments. When the stockholder sues, the attorney employs procedural objections and pretrial discovery tactics deliberately designed to exhaust the claimant's financial staying power, and then, using corporate funds, offers

22. See Model Code of Professional Responsibility EC 7-3, 7-8, DR 7-101(B)(2) (1979). But cf. Model Rules of Professional Conduct Rule 1.2 (1983) ("Legal representation should not be denied to people . . . whose cause is controversial or the subject of popular disapproval.").

Where the lawyer concludes that he has no influence on illegal or unethical client practices or intentions, there may be an obligation to withdraw. MODEL CODE OF ProFESSIONAL RESPONSIBILITY DR 7-102(7), DR 2-110(B)(2) (1979); MODEL Rules OF PRoFESSIONAL Conduct Rule 1.16(a)(1), Rule 1.2(d) (1983). Without denying the ethical rectitude of withdrawing and letting another lawyer take the case, that practice, as far as we can tell, is neither descriptively nor normatively important in large law firm practice. Our four images, therefore, focus on the various ways lawyers exercise (or fail to exercise) "voice" as contrasted with "exit" in relationships with the client.

23. We exclude from our discussion here, and from our typology, flatly illegal attorney actions, on the assumption that they are rare in large firm legal practice. 
to buy the stockholder out (for a low sum), thereby foreclosing exposure of the corporate president's misdeeds. In short, the attorney acts as a cynical manipulator of the tools made available by a complex legal system. He takes advantage of the forms and the letter of the law rather than the spirit or intent, to maximize his client's narrowly defined and essentially asocial goals.

The lawyer in this scenario might argue that he did not determine or influence the corporate president's goals or policies; using our terms, he might say he was merely a conduit, complying with his professional obligation to "represent a client zealously within the bounds of the law."24 But the conduit, as defined above, not only carries out the client's wishes, he also conveys to the client the requirements of "the law," interpreted in a straightforward manner. Hence the conduit sometimes influences client policies and tactics toward conformity with the law. Here, however, the "manipulator" exercised no social control function at all. The attorney did not inform the corporation's president that the stockholder's charges and his subsequent lawsuit had merit in the eyes of the law, and he did not concern himself with the propriety of taking fees from "the corporation" to defend its president against charges that the president was defrauding "the corporation." The lawyer's conscious manipulation of the legal pleading and discovery rules to defeat a just claim did not suggest to the president that the law should be viewed-in this case or in future cases-as anything more than a set of morally meaningless obstacles to be circumvented or used as a shield.

It is not difficult to imagine a more extreme version of the "manipulator" role. Consider a similar situation in which the corporation's president, confused about the implications of the minority stockholder's charges, expresses dismay and uncertainty to his attorney. The lawyer responds by affirmatively suggesting that the best course would be to deny the charges, constructs a plausible rationale for the president's actions, ties the claimant up in expensive litigation, and buys him out with corporate funds. In this version, the lawyer, like the influential counselor of the dominant image, actively influences the client's goals and

24. Model Code of Professional Responsibility Canon 7 (1979). This duty includes a plausible legal purpose for any delaying tactics, Model Code of Professional Responsibility DR 7-102A(1) \& (2) (1979); Model Rules of Professional Conduct Rule 3.2 (1983), though such a requirement is not much of a hindrance in practice. 
policies. But in exerting influence, this attorney does not draw upon "independent" standards rooted in the law, public policy, and common conceptions of fair dealing; instead, he takes as his normative benchmarks a cynical view of the law and a short-term, profit-maximizing version of his client's (or its president's) interests. In this extreme counter-image, the lawyer both cynically manipulates the legal system and actively urges his client to seize whatever short-run financial advantage can be obtained by legal tactics. ${ }^{25}$

In a less extreme version, the manipulative style of practice does not involve overt advocacy of cynical corporate action. Consider a case in which a lawyer, noting a procedural delay in the issuance of a product safety regulation, simply tells his client that to market a nonconforming product during the next four to six months would be "legal" under present regulations, and that the pending regulation, when issued, probably would not affect the client's nonconforming products already in the stream of distribution. Regardless of the lawyer's intentions or personal views, such bare bones advice may influence the client's intracorporate battles, undermining those who argue against risking damage to the corporation's reputation by marketing arguably dangerous or substandard products. The manipulator influences corporate practices toward treating anything which is not illegal as acceptable, the mirror image of the lawyer as influential and independent counselor.

While extreme versions of the manipulator image may not be a common form of large firm practice, a milder form of cynicism may pervade a good deal of corporate practice. To many practitioners, a considerable proportion of their work has little to do with bringing about fair dispute resolution or responsible busi-

25. A few additional examples will help flesh out this counter-image. As tax counselor, the lawyer-as-manipulator might suggest that the client take a certain write-off, even if the lawyer believes there is a 60 to 80 percent chance that it would be disallowed by an Internal Revenue Service audit, pointing out to the client that the interim return on the money saved in current tax payments probably would outweigh any penalty imposed by the IRS. A manipulator might suggest to a client that chances of obtaining a desired municipal license would be improved if a contribution were made to city political figures before a formal application is filed. In a variety of contexts, a manipulator may urge nondisclosure of legally damaging information on the grounds that chances of discovery or effective legal attack would be slim. He might advise the initiation of lawsuits or heavy discovery demands primarily as diversionary or cost-imposing tactics. In the vernacular, the manipulator plays only "hardball," and encourages his client to do the same. 
ness practices. Consider the assiduous creation by large firm lawyers of complex tax avoidance arrangements. A good deal of "tax work" can be construed primarily as the restructuring of corporate transactions, fund transfers, and accounting methods solely to exploit legal loopholes-all entirely ethical conductbut without any real concern for fundamentals of financial or economic efficiency. ${ }^{26}$ Consider also the countless hours spent by large firm lawyers on corporate takeover battles. The legal issues involved often seem to have become unhinged from serious issues of public policy and fairness. ${ }^{27}$ In these areas, the practice of law becomes a complex, advantage-seeking game, in which the lawyers' goal is to outsmart the actual or potential opposition. The lawyers' personal rewards come from the challenge of competition and the sense of being clever, and not from furthering justice or economic efficiency. ${ }^{28}$

One might argue that the same is true of much "securities work." Lawyers' work on disclosure statements rarely involves fundamental issues of preventing fraud. Their job is to draft

26. It may be true that, as an experienced tax specialist in a Wall Street firm wrote us, "We spend most of our time advising clients that it is the economic and business substance of a transaction that counts and not its form." Nevertheless, the categories of the tax code are not without effect. Tax lawyers are obliged to inform clients that certain variations in depreciation methods, corporate structure, and cross-jurisdictional tax rates will often have a significant effect on the profits of an enterprise. It is reasonable to assume that some lawyers have strong-willed, forceful personalities and actively urge their clients not to ignore opportunities for tax savings. And at least some clients respond by asking their lawyers to restructure transactions specifically to gain tax law advantages.

27. One experienced New York attorney wrote us that while he was proud of his independent contribution to the consummation of some mergers that he thought made economic sense, on the other hand:

There have been a great many mergers which were just a lot of paper shuffles where the world was the same after the deal as before. The only thing we accomplished was to pay premiums to a bunch of anonymous shareholders and to deprive a lot of vulnerable people of job security.

28. President Bok wrote:

I do question whether most of the legal marathons . . . that clutter the (antitrust) field are truly worth the money and time they cost. . . . I recently approached ... one of the country's leading antitrust experts-and asked him whether he would dispute my claim that over half of all antitrust decisions have no demonstrable effect in furthering accepted economic goals. Instead of chiding me . . . he replied that he would push the figure up to at least 75 percent. Bok, supra note 1 , at 11 , col. 1 .

One of our respondents, a senior partner in a large San Francisco firm, referred to his defense of an antitrust action in which "the charges are without merit, the case has dragged on for years and is extremely expensive. It raises serious doubts in my mind as to the social utility of such litigation ....." 
opaque language that will help parry possible future lawsuits by sophisticated securities traders who discern the possibility of recouping losses through lawsuits alleging deception, inside trading, and the like. Some serious scholars argue that because the market is dominated by well-informed investors, most of the Securities Exchange Commission disclosure obligations impose substantial costs, while providing few benefits to the investing public. ${ }^{29}$ This argument may be somewhat overstated, but many securities lawyers must wonder whether their work has anything to do with justice or with sensible public policy. Instead, they may believe that they are simply engaged in the manipulation of language and law-not reality-for their clients' advantage, in combat with adversaries, real or potential, who do the same.

\section{WHY THE LAWXER-AS-INFLUENTIAL-AND-INDEPENDENT- CounsElor Role IS LIKELy TO BE EXTRAORDINARY RATHER Than ORDINARY}

The four images sketch dimensions of corporate practice in extreme terms. The very size and diversity of large firms reminds us of the range of roles performed by large firm attorneys. These roles undoubtedly vary according to client, legal specialty, and stage of lawyer's career. Hence, the four images are not mutually exclusive, but coexist, merge, and overlap. We are interested in what pushes lawyer actions toward each of these images and which images tend to predominate under the conditions of modern practice.

It would be unrealistic to imagine that the influential and independent counselor role characterizes the work of most large firm lawyers most of the time. Inevitably, routine and technical labor takes up a lot of time in even the most creative and influential jobs. One initial hypothesis might be, therefore, that large firm lawyers, like other elites, occasionally play influential, independent roles, in which their own ideas and skills truly shape events, court decisions, or corporate behavior. Sometimes corporate firm attorneys do have something to do with justice, but this hypothesis is not inconsistent with a "counter-image hypothesis" that most corporate attorneys play more routine, technical, subordinate roles most of the time. The issue remains: What

29. See, e.g., Benston, An Appraisal of the Costs and Benefits of Government-Required Disclosure: SEC and FTC Requirements, 41 LAW \& Contemp. Probs. 30 (1977). 
proportion of large firm lawyers' work comports with the influential and independent counselor image, and what proportion more closely resembles each of the other images? And what factors affect and change the balance?

It is tempting to imagine that in an earlier era, when a much smaller number of Wall Street partners interacted with a smaller number of top corporate executives, the influential counselor role was rather prominent. But it is also quite possible that it was not prominent-we simply do not know. Data is lacking about contemporary large firm practice, and any historical baseline is even more obscure. Based on the general structural conditions of large firm practice today, however, we will outline a series of hypotheses supporting the proposition that the influential-andindependent-counselor role probably has been declining as a proportion of the large firm lawyers' work, to the point that it is now comparatively infrequent.

\section{A. Hypothesis One: The Clients of Large Law Firms Increasingly Do Not Want Their Lawyers to Act in the Dominant Image}

The corporate giants whom large law firms serve, and some of the firms' smaller corporate clients as well, have become increasingly sophisticated in the purchase of outside legal expertise. The more sophisticated the client is in dealing with legal problems, the less one would expect the dominant image of the outside lawyer to prevail. The importance of client sophistication is reflected in a response to this paper by a New York City tax and securities law specialist who was formerly associated with a large firm but is now a senior partner in a twenty lawyer firm that often represents individual entrepreneurs and privately held companies. When dealing with these smaller enterprises, he notes, his own experience in a particular class of transactions is usually greater than his client's, and his business as well as his legal judgment is more highly valued. Rather than simply "explaining" various options and risks, and leaving the decision to the client to decide, this attorney claims he is more often drawn into the role of forceful advocate for a particular course of action and is compelled to play a larger role in carrying it out. Therefore, the larger, more specialized, and more fully staffed the corporate client, the less likely the outside lawyer's own "autonomous" judgment and advice will effectively influence the actions ultimately taken, and the more likely the lawyer will sim- 
ply be a "reporter" of significant information. ${ }^{30}$

Client sophistication may derive from various sources. First, corporate managers increasingly are trained to anticipate legal problems and to handle the alternatives engendered by legal matters. Not only are corporate managers more and more likely to be M.B.A.s, but about one-sixth of the senior managers of large corporations are lawyers who have chosen to move into managerial roles. ${ }^{31}$ Further, large corporations now have organized staff units that specialize in particular activities engendering frequent legal problems and that control corporate relations with outside legal counsel. These staff units include not only large inside corporate legal departments, but regulatory affairs and environmental policy units, real estate acquisition units, employee benefit plan and affirmative action units, tax planning units, Western European marketing units, and so on.

For such managerially and organizationally sophisticated corporations, careful planning often precedes contact with large law firm attorneys. Their outside lawyers are most likely to be called on to research delimited issues or "to run with the ball" toward predetermined objectives. The tasks corporations ask their outside lawyers to perform may be complex or involve nonroutine legal issues, perhaps increasingly so as inside counsel or special units take over recurrent, more administrative tasks. ${ }^{32}$ And certainly, large firm attorneys' efforts on delimited but complex questions can uncover possibilities for adding worthwhile insurance arrangements and for changing the details of corporate

30. Thus Professor Charles Fried recently wrote that "the ideal type of lawyer as all-purpose, wise counselor comes closer to being realized in smaller firms dealing with new and smaller clients and in law firms away from the legal meccas of New York, Chicago, Los Angeles and Washington." Fried, The Trouble With Lawyers, N.Y. Times, Feb. $12,1984, \S 6$ (Magazine), at 61 .

31. One survey found that $16.4 \%$ of senior managers were lawyers. Lynch, The Growth of In-House Counsel, 65 A.B.A. J. 1403 (1979).

32. Thus, to Douglas Rosenthal, a partner in the Washington office of a large firm, rising legal bills mean that:

Outside counsel are doing less corporate "housekeeping" (e.g., maintaining corporate records) and less relatively routine drafting, such as licensing agreements and periodic federal and state regulatory filings. Instead, law firms are spending more time on special, nonroutine legal problems, such as litigation (particularly complex law suits requiring large teams of lawyers), or representations in tax, trade and energy matters demanding special expertise that is not easily obtained in-house.

Rosenthal, U.S. Corporate Lawyers Face Competition, Financial Times (London), Aug. 13, 1981 , at 12. 
courses of action. But managerially and legally sophisticated clients, we would expect, are not particularly receptive to outside input about the choice of goals or strategic plans, except in relatively uncommon circumstances. ${ }^{33}$

Are not "relatively uncommon circumstances" likely to emerge with considerable frequency in a rapidly changing national and world economy and in a legal system that constantly generates new regulatory programs and tax code amendments? Perhaps so, but the corporate need for outside legal representation in adapting to such changes must be assessed in light of the growing internal corporate capacity to cope with change and uncertainty. Once corporations establish specialized units to deal with particular legal frontiers, the hypothesis would be, first, that new legal changes within such an area automatically will be detected by or referred to the specialized unit, which can then draw upon past experience in adapting to similar legal challenges; and second, that when outside legal counsel is sought, the specialized unit, because of its accumulated experience, will dominate the choice of appropriate legal action or response.

Fifty years ago, for example, labor law was still in flux. Lawyers presumably could influence their clients' expectations and attitudes toward unionization and collective bargaining, and, if they chose to, could encourage compliance rather than footdragging and legal or political countermeasures. Today, corporations are acclimated to the strictures of labor law, and the tasks of labor lawyers by and large have become more technical; labor lawyers are more likely to serve solely as conduits for the corporation's full-time industrial relations staff, not as counselors influencing the corporation's fundamental strategies or philosophies of labor relations. To find frequent recourse to the independent counselor image, we must look to situations in which lawyers are called upon to advise corporations coping with wholly unfamiliar territory, such as their first encounter with a "hostile takeover," beginning trade with the Peoples' Republic of China, or attempting to protect property interests in postrevolutionary Iran. ${ }^{34}$ But even in these situations, sophisticated clients

33. The increasing difficulty of influencing corporate clients is not unique to lawyers. The growth of "managerialism" has also decreased the influence of corporate boards. These boards, and the lawyers who serve on them, like large firm attorneys, find it difficult to exert influence.

34. Similarly, Douglas Rosenthal predicts that as more foreign corporations set up shop in the United States, American lawyers will be increasingly called upon to play what 
may have the internal resources to make necessary decisions and control the lawyers' work product.

Another example concerns new domestic safety, health, and environmental regulations. The fundamental governmental power to regulate in these areas is rarely under contention. Rather, the key issues involve the technical and economic aspects of particular regulatory proposals or requirements. Corporate scientists, engineers, and economists are likely to develop crucial arguments. Any independent contribution by lawyers, beyond their role as legally articulate conduits, is more likely to resemble the procedurally dilatory tactics of the manipulator. At the enforcement level, the corporation may dispatch its outside lawyers to engage in procedural battles, or file requests for exceptions, but not to develop and help implement intracorporate compliance programs. And if the corporation develops better working relationships with regulators, as tends to occur over time, lawyers become less frequently involved, thereby reducing the occasions in which outside counsel serve as influential and independent counselors.

Might the very size of many sophisticated corporate clients, which inevitably leads to interdivisional and interpersonal power struggles, draw outside counsel into the role of autonomous and influential advisor? Corporate response to new, legally risky business opportunities is often contested among corporate managers. One might expect such internal "hot potatoes" to be referred to outside counsel for independent judgment. Sometimes this does occur, ${ }^{35}$ but currently, we hypothesize, large firm practice tends to insulate the lawyers from learning about and dealing with these struggles. Corporations often do not want "outsiders" to know of their internal divisions. The outside lawyer, whose contact is often limited to particular corporate officials, may not be apprised of intracorporate opposition to those officials' views. In addition, large firm attorneys, even when aware of

we have called the independent counselor role, "identifying and anticipating legal, political, and even financial, and public relations problems likely to emerge as corporate investment and marketing strategies are put into effect." Rosenthal, New Opportunities for U.S. Law Firms, Financial Times (London), Aug. 20, 1981, at 12.

35. One senior partner in a large New York City firm, when asked to describe matters in which he believed he played an independent counselor role, referred to a case in which he represented a large law firm whose managing partners were divided about the proper response to a charge of unprofessional conduct. Management division, he said, drew him into a more assertive role. 
internal pathologies and power struggles, may believe that their independence requires them to abstain from influencing intracorporate conflicts. In sum, the outside lawyer is distanced from the users of his knowledge, somewhat ignorant of the full range of corporate needs, and disadvantaged in competing with other advisers for the corporate leader's ear.

\section{B. Hypothesis Two: Large Firm Attormeys Infrequently Have the Close, Personal Relationship with the Corporate Decisionmaker Required by the Dominant Image}

The significance of personal lawyer-client relationships to the lawyer-as-independent-and-influential-counselor role is suggested by the comments of a senior partner at a large San Francisco law firm:

I find that I more often fulfill the role of "independent counselor" with smaller clients whom I know personally. In dealing with larger corporate clients who have an intelligent and competent management team, I am often faced with decisions which have already been made and asked to support them with legal authority or to make suggestions for minor modifications to meet the requirements of existing law. In such cases, I am more of a "conduit" or an "insurance man" . . . . However, business clients with whom I have had a relationship over a long period of time do look to me for independent business advice as well as for legal counsel.

To some extent, the lack of a close, personal relationship with the corporate decisionmaker comes from the rise of the team approach to management that is characteristic of the large modern corporation. Even if the partner is "close" to the corporation's Chief Executive Officer or General Counsel, to exert influence the lawyer must now convince a team whose members are likely to have their own advisors. ${ }^{36}$

36. The exception that proves the rule, perhaps, is that large firm lawyers, when asked about cases in which they served as independent counselors, often refer to matters in which they served individuals. A New York lawyer told us with pride about a case in which he helped bring about a measure of peace, at least in the financial realm, to warring members of a wealthy family whose antagonisms threatened the viability of its enterprises. A partner in a Philadelphia firm wrote that while he thought there has been a change in the relationship between corporate lawyers and corporations that has substantially reduced lawyers' influence on corporate policy, "There are still enough affluent people among the client stables of some big firms to keep a small cadre of personal lawyers reasonably busy ... . . The personal lawyers . . . are able to become 'statesmen' with respect to their individual clients, and frequently their clients are important people." 
To a greater extent, obstacles to a close, personal relationship arise from the changing market for legal services. Much of the large firm's work now consists of specific projects handled as local counsel to a corporation, rather than as continuing general counsel to corporate headquarters. Inside corporate legal departments have emerged as purchasers of particular outside lawyers' services for specialized jobs; they try to parcel out their company's legal work to a group of law firms. In such cases, it is more appropriate to speak of lawyer-client transactions than of the lawyer-client relationship. Finally, corporate inside counsel, who have an incentive to build up their own departments and enhance their intracorporate influence, may actively try to prevent close personal ties between outside lawyers and top management. As one senior partner in a New York law firm told us, "They want no one between them and their chairman."

The work distribution patterns in large law firms may also support the second hypothesis. First, even if a partner has the requisite relationship with the client, he may fail in the difficult task of "directing a legal orchestra." This partner will assign most of the client's legal work to other partners and associates. It is in the performance of their work that influence and judgment must be exercised. Yet these lawyers do not have the close personal relationships necessary to influence top corporate managers and may opt to let the client control how their work proceeds. Second, given the desire of most firms not to get too tightly coupled to their existing clients, they reward specialization over client relations. Third, internal pressures for "production" and efficiency have created a highly pressurized and fast-paced workplace that, according to some lawyers, operates as a barrier to the cultivation of close personal relations between corporate lawyers and their clients. ${ }^{37}$

37. A partner in a large Philadelphia firm who read a draft of this paper wrote: When I came to Philadelphia in 1972 [after ten years in a Wall Street firm] . . . partners were expected to charge 1,200 hours per year. (Expected in the sense that if a partner fell too far below that figure his compensation might be affected.) Now our partners are expected to spend 1,560 hours on clients' work annually, many spend much more . . . . At this pace there is very little time for the thoughtful reflection that the minds engaged in corporate work are probably capable of. Most such lawyers are jumping from one job to another on, in my opinion, a relatively technical and uncreative level (although the product would appear superb to an outsider)-with no time to influence corporate policy or to be the grey-haired advisor type described in your essay. 
C. Hypothesis Three: Large Firm Attormeys Interpret Their Tasks to Avoid Practicing in the Dominant Image

It is not only in law practice that growing sophistication among clients has tended to relegate professionals to narrower and more technical roles, thus weakening their general influence. For example, these trends have also occurred in architecture and in the ministry. But these professions responded by broadening their concept of client service. When, because of the rise of allied professions, there was decreased demand for the architect to serve as influential controller of all aspects of building design, architects often became "the leader of a multi-professional team," including engineers, interior designers, landscapers, and environmental impact specialists. ${ }^{38}$ In the same way, when there was less client demand for "the clergyman's privileged access to a body of doctrine," he regained his autonomy and influence by becoming a "cultural leader, teacher, medical or social worker."39

Large firm lawyers, however, seem to have willingly adopted a professional ideology that suggests that the lawyer should not be independently influential, but rather a technically adept specialist who tells the corporate manager, "here are the legal risks, you make the decision." Not all lawyers, and surely not the very best ones, do that. But the legal decision versus business decision dichotomy stressed in much legal writing may help explain why lawyers willingly accept the role of the conduit or insurer, instead of striving to become a creator of multidisciplinary preventive law programs or corporate compliance policies. The same abnegatory self-image encourages lawyers to handle litigation, contracts, and acquisitions as individual sets of legal problems, rather than occasions for affecting corporate policy. The lawyers' reactive, wait-in-the-office-to-be-called professional posture helps explain why, when faced with a product liability case, lawyers rarely initiate a change in the corporate product design and testing system, or why, in securities work, lawyers rarely take the initiative to join with accountants in designing corporate financial reporting systems. ${ }^{40}$

38. P. Ellyotr, The Sociology of the Professions 125 (1972).

39. Id. at 126.

40. Gilson observes that lawyers' role as influential "transaction cost engineers" in corporate acquisitions is in danger of being reduced to the role of conduit and draftsman as investment banking firms aggressively assemble teams of their own lawyers, 
An increasingly "professionalized" bar, moreover, has come to emphasize craft skills and de-emphasize personal values. The profession's concern with 'craft overshadows the dominant image's mix of law and business judgment, and encourages the view that lawyers are not responsible for influencing their clients. Further, the professional ideal of zealous representation overshadows the expression of personal opinion. Thus, large firm attorneys probably would think it unprofessional to urge their clients, on grounds of the lawyer's political and social beliefs, to comply rapidly and wholeheartedly with laws that the lawyer personally endorses.

In one sense, the image of the influential and independent counselor is not a "professional" one. In the pantheon of the profession, places are assigned to the most legally learned and arcane specialists, the "lawyer's lawyers." The lawyers who are most businesslike and most "political," the Lloyd Cutlers, are seen as somewhat deviant.

\section{Hypothesis Four: The Dominant Image is Extraordinary Because Heroism is Rare}

Our three earlier hypotheses, emphasizing market-based, structural, and professional impediments to the independent and influential counselor role, suggest a final hypothesis stressing the qualities necessary to surmount the impediments. Implicit in the dominant image is a notion of leadership. But leadership, and its concomitant, heroism, are not common. Fear of losing clients or of treading in areas where the lawyer does not have certain knowledge, among a host of other reasons, makes it is unreasonable to expect that the dominant image will be the norm.

\section{Corporate Lawyers' Responses to Our Hypotheses}

To obtain a tentative assessment of the hypotheses set forth in the preceding section, we sent copies of a draft of this paper, together with an open-ended questionnaire, to twenty-five partners in twenty-three corporate law firms. Most of these firms were located in New York City, but some were in Washington, D.C., San Francisco, Philadelphia, Hartford, and Omaha. This "sample" was obviously neither large nor reliably representative.

economists, and accountants, thereby providing a broader range of influential risk-reducing, deal-structuring services. Gilson, supra note 4, at 301-02. 
It was, moreover, a distinctly nonrandom sample: The lawyers we asked to respond were either our personal friends, our exclassmates, or the personal friends of academic colleagues. Only the ties of friendship, we reasoned, might induce overworked attorneys, for whom "time means money," to read a lengthy paper and write a response. But even those ties were not strong enough in all cases. We received fourteen responses. Most were from partners between the ages of forty-five and fifty-five, working in a variety of legal specialties; a few were from younger partners and several were from senior partners in their sixties. In addition, we sent copies and questionnaires to fifteen associates in fifteen firms and received six responses.

The reactions of this small group of corporate lawyers cannot be reported as "representative." A full-scale inquiry would require a sample stratified along many dimensions including age, city, legal specialty, and type of client. More important, to assess the influence of corporate lawyers, the attitudes of those who consume and evaluate the firms' services, corporate managers and inside counsel, would have to be considered. Nevertheless, we feel justified in reporting the responses we received because they reflected a high degree of unanimity, which suggests that a broader sample would not produce markedly different results. Moreover, our questionnaire was not designed as a survey of the quantitative frequency of particular attitudes; rather, it sought indepth analysis of our hypotheses from intelligent and knowledgeable observers of the corporate lawyer's world.

Only one of the twenty corporate lawyers who responded to drafts of this paper took serious issue with our hypotheses concerning the growing infrequency with which large firm lawyers comport with the image of lawyer as influential and independent counselor. ${ }^{41}$ Most expressed affirmative agreement. One minor dissent was filed by a partner in a large Omaha firm who felt that close relations with top corporate executives were still common for partners in that firm. More typical, however, were the comments of a senior partner in a large San Francisco law firm: "As inside .. general counsel for larger clients takes a greater role in dealing with management and outside counsel, the role of outside counsel as 'independent' counselors will decrease. They

41. See Rosenthal, supra note 32 , at 12. 
will have less contact on a daily basis with policy makers who make management decisions."

Most of our respondents readily mentioned recent matters in which they felt, in response to our question, that they had "done the world some good." For example, an antitrust lawyer referred to a case in which her efforts helped "clarify the law pertaining to the copyrightability of certain aspects of computer programs." Another felt he had played an important role in developing the economic and legal arguments for a merger of two petroleum companies and in defeating legal challenges to the transaction. A San Francisco attorney expressed pride in having helped equipment leasing companies handle a series of novel problems, thus contributing to the development of new methods for financing equipment acquisitions in the airline and computer industries. He also felt he had played a constructive role in mediating between industrial clients and public officials to "develop cost efficient and effective methods to clean up [PCB] contamination and to prevent future contamination." A New York attorney wrote that when serving on corporate boards of directors, outside lawyers not infrequently "serve as the formulator or harmonizer and in that capacity play a really important corporate strategy role." Moreover, in his experience, the outside lawyer, by "bringing his expediting, rationalizing and organizing skills to the party," often "promotes efficiencies in corporate bureaucracies" where indecisiveness and "fuzzy thinking" are common.

A litigation partner in a New York firm told us that in the course of defending a product liability action, he learned facts that led him to seek out the company's chief executive officer to tell him that the corporate product safety and quality control systems "were a mess." Other litigators thought they had performed a socially useful role when they had repulsed unfounded lawsuits against their clients. A senior partner in a New York firm felt he had been an influential and independent counselor when he persuaded a corporate client that its long-term interests would best be served by instituting an affirmative action plan rather than litigating with the Equal Employment Opportunity Commission. Another attorney described as follows his role in representing a large brewing company involved in a hostile takeover attempt:

We were convinced that the tender offeror was a "liquidator" who would have closed down the company to sell its assets for a 
"quick hit" profit. In these . . . transactions the antitrust laws were an important shield and weapon. Management had to rely on our advice because they lacked the internal expertise to challenge it. We succeeded through a long series of struggles both by rendering independent judgment and being craftsmen and advocates. I don't know whether we served some cosmic public interest, though we think we did by keeping this company in business in a concentrated industry; but . . . helping to save the jobs of thousands of employees was a tremendously rewarding feeling not matched by any single "public interest" enforcement prosecution for which I was responsible during my six years of government service.

Nevertheless, all our respondents acknowledged that serving in the "dominant image" was clearly the exception rather than the rule in corporate practice. A partner in a large "midtown" New York firm wrote:

I think that the "independent counselor" is a rare position. Some of the very large and "prestigious" firms certainly function in this capacity relatively frequently, and a few senior partners in those firms perhaps function in that way a considerable part of the time. My sense, however, is that even the lawyers in firms which can . . . be seen as being quite "powerful" are generally powerful because they choose to serve (in a relatively effcient and powerful manner) forces which are themselves socially and economically powerful.

But a longtime partner in such a "prestigious" firm did not feel that the independent counselor role predominated in his "general corporate practice":

Obviously, my advice to clients affects their decisions. Their decisions are affected for example by advice that certain proposals are illegal or would result in other legal detriment. My advice also affects decisions in selecting among alternatives and may be based on many factors not limited to legality, including ethics, public relations and other judgments. Most of my work, however, could be described in your terms as "conduit" effecting business decisions.

And one of his partners (age fifty), specializing in "tax work primarily for large corporate and investment banking clients," wrote, "I rarely play the role of influential and independent counselor as described in your paper, and I would guess that this would also be true of most of my partners." A senior partner in another long-standing New York firm estimated that "not over five percent" of his work fell in the "influential and independent counselor category."

One of our respondents, a forty-year-old litigator, stated that 
forty percent of his work was of the "independent counselor" nature, and a forty-three-year-old partner in the Washington office of a large firm estimated that this was twenty-five percent of his work. The modal response, however, was that of a litigation partner in a large firm who stated: "In my experience, the 'dominant image' is neither dominant nor the ideal, but rather is expected to be and is the exception." Furthermore, many of the respondents who mentioned aspects of their work that corresponded to the dominant image also emphasized that it tended to occur in "relatively small and peripheral matters." Finally, most of our respondents characterized their work as falling predominantly in the "conduit" or "insurer" categories. As might be expected, most said that they and their partners never resembled the "manipulator" described above. ${ }^{42}$

\section{The Declining Social Significance of Large LAW Firm Practice}

Why would outstanding young people enter large firm corporate legal practice rather than seek to perform other social roles that make the economic pie grow larger or distribute economic resources and services more fairly? Aside from the financial security, prestige, and the elevating sense of contact with important actors and events, one reason might be that large firm lawyers play significant roles in the legal control of corporate enterprise and in the rationalization of economic activity. In our decentralized, law-pervaded system of social control, those trained in the law have often been perceived to have great opportunities. Lawyers can be influential mediators in bringing about corporate legal compliance, or reasoned defenders against excessive and unreasonable instances of state intervention. By bringing together legal and business knowledge, they can influence the settlement of disputes and the development of business practices that meet the demands both of efficiency and equity. By increasing corporate sensitivity to the inchoate structure of the legal and political environment, they can prod business institutions toward

42. To the extent large firm lawyers have lost the possibility of influencing corporate decisions, not only will the proportion of practice in the dominant image decline, but one would also expect a decline in the proportion of practice conforming to the lawyer-as-manipulator image. Thus, it is not inconsistent for large firm lawyers to maintain that they have an increased ability to resist ethical conflict while at the same time having a practice that has diminished social and ethical significance. 
the fulfillment of public aspirations. These opportunities demand the talents of some of our best minds.

Yet the experience of our small cadre of corporate lawyer respondents is that the influential and independent counselor role is now an exceptional rather than a common aspect of large law firm practice, especially when lawyers serve large corporations. The trends in client demands and law firm organization reinforce that conclusion. The social significance of large law firms, therefore, seems not to be that these agglomerations of well-educated, highly skilled, personally forceful, and richly compensated lawyers regularly have a significant independent influence on corporate decisions, or on public policy.

It is striking, in fact, that contemporary corporate lawyers often seem to reject even the aspiration to serve as molders of corporate and public policy. Perhaps this rejection is a manifestation of cognitive dissonance-when experience differs from normative beliefs, either the norms or the experience must be denied, and lawyers, being pragmatists, reject the norms. In any case, few of our respondents, it seems, would agree with either the descriptive or the normative thrust of Dos Passos' 1907 observation of the corporate bar: "The lawyer boldly enters into the business end of his client's transactions-he sells him prudence and experience, sometimes even usurping the client's discretion and judgement." 43 Today, many members of the corporate bar believe that lawyers should not sell; clients should choose what they buy and lawyers must guard against imposing their values on their clients. One partner in a well-known Wall Street firm wrote us that in his view "influence on corporate decisions" is not a proper criterion for evaluating the social contribution of lawyers: "Corporate executives are supposed to make decisions, not lawyers. Indeed, I consider . . . lawyers on boards of directors as acting in a nonlegal capacity. Lawyers acting in a legal capacity should, it seems to me, be making evaluations without business responsibility."

To the extent this view is typical, the modern lawyer thus

43. J.W. Hurst, The Growth of American Law: The Law Makers 342 (1950) (quoting Dos Passos); see also, Swaine, The Impact of Big Business on the Profession: An Answer to Critics of the Modern Bar, 25 A.B.A. J. 89, 171 (1949); E. SMIGEL, supra note 8. But see Report of the Comm'n of Professional Ethics of the New York State Bar Ass'n 9 Jan. 23, 1948), quoted in H. DRINKER, Legal. ETHics 102 n.10 (1953) ("The function of the lawyer in our changing society is constantly developing. Today, he is called upon less often for dramatic . . . exploits than for wise counsel in every phase of life.") 
stresses his independence, forsaking influence. He apparently enshrines client control while abdicating responsibility for the social and economic impact of his client's actions (and of his own actions in carrying out his client's decisions). He chooses to remain a corporate lawyer, rather than seeking to become a businessman, director of corporate security, or politician, because he finds satisfaction in his craft, in the game of lawyering. But the lawyer seems to eschew power and its companion, responsibility, and as one of our respondents puts it, he is primarily an "information supplier."

In a modern, legally complex society, significant social benefits undoubtedly flow from large firm lawyers' service as information suppliers, conduits, and insurers. In summarizing complex bodies of law, explaining regulatory requirements, writing opinion letters, and guarding against adverse contingencies, corporate lawyers not only contribute to compliance with the law, but also reduce uncertainty and thereby facilitate new economic ventures. As litigators, they often advance just claims and repel unjust ones. By helping clients obtain legally created benefits and protections, lawyers often help contribute to economic well-being. The sophistication and difficulty of these tasks, as well as their importance in our legal order, perhaps justify large law firms' absorption of many of the nation's most hardworking and intelligent young men and women. There is not much of an argument for the proposition that our most important economic entities should be represented by inarticulate, slow-witted and unimaginative attorneys.

But it would be naive to think that legal imagination and craftsmanship, neutrally applied in support of goals decided upon by corporate managers, is necessarily socially beneficent. While reporting and implementing the law's requirements sometimes helps prevent abuses that stem from market imperfections, the law can also be used as a weapon to exploit market dominance and to defend (or minimize the penalties for) corporate abuses of trust. Legal craftsmanship can be used either to help corporations carry out or to help them frustrate public purposes, to help businesses implement innovative practices or delay innovations by competitors. When a lawyer functions solely as an information supplier or conduit, he draws upon his judgment of legal consequences, and not upon his autonomous evaluation of social consequences, political wisdom, or good business prac- 
tices. Thus, he contributes to social welfare only when the law as applied to a particular situation has a positive impact on economic efficiency or on equity, and often this will not be the case.

The gap between being a provider of information about legal consequences, on the one hand, and being a provider of forceful advice based on autonomous assessment of consequences on the other hand, was reflected in statements by many of our respondents that most of their work was "morally neutral," or "technical," or "puzzle-solving." One lawyer wrote, "In practice, lawyers do not think about doing good," and another, "Lawyers are not in a good position to judge whether their clients' rights should have been vindicated."

We do not know how representative such opinions aresurely many lawyers would disagree-but it would not be surprising if these opinions were the dominant view. Perhaps this view is what one should expect in a modern legal system that is not based on a small number of simple laws that reflect agreed-upon principles, but is packed with thousands of confusing statutory amendments and regulations that reflect ad hoc compromises among conflicting political interests and economic philosophies. Indeed, it is hard for a lawyer to know what is "right" or "socially responsible" when assessing whether his client should yield to a particular claim under antitrust, securities, ${ }^{44}$ foreign trade, or regulatory laws. For example, while one lawyer might feel he is serving the public interest in resisting a corporate takeover attempt because the advancing "shark" might close down some of the "victim's" facilities, the lawyer for the other side may believe he is serving the cause of economic efficiency.

Given the imponderable value conflicts and factual issues at stake in such matters, the lawyers' retreat to the agnostic, clientserving conduit role is understandable. Thus, a partner in a Wall Street firm wrote us: "I have found a corporate tax practice very satisfying in many ways, but I have no idea whether it has any more than a minimum social value or utility." Another corporate lawyer wrote us that he felt uneasy about helping his client evade another country's foreign exchange laws by taking advantage of what he believed to be an unintended loophole in a poorly conceived statute. He added, however, "If the same loophole existed in U.S. law, I would have no qualms about exploiting it.

44. See Benston, supra note 29. 
Perhaps the reason is that I believe that U.S. law is sophisticated enough that most loopholes are there by design, not oversight." Like other respondents, this attorney justified his role as nonjudgmental conduit (or even as manipulator) by recourse to the lawyer's familiar faith that the adversary process and political pluralism will produce, on balance, a set of laws that approximate some version of the public interest. Thus, the constraints and opportunities presented by the laws on the books, discounted by the likelihood of their enforcement-and not the lawyer's autonomous judgment-are regarded by the lawyer-as-conduit as the proper measure of client conduct. ${ }^{45}$

Might it be otherwise? Is there any possibility of a broader influential and independent counselor role in large law firms? The notions expressed by some of our respondents-that it is not a proper normative ideal, either because what is "right" is too ambiguous, or because the lawyer has no expertise in or responsibility for business judgments-go too far. What is "right" often is ambiguous, and in general it may be defensible for corporate lawyers to treat "the law" and the probabilities of its enforcement as the sole touchstone for the advice they give their clients. Hence one would not want or expect most large firm lawyers to play the influential and independent counselor most of the time. Nevertheless, there surely are particular cases in which a more active role is both possible and justifiable. On occasion, what is "right" will not be so obscure: The law, and client actions that technically would avoid legal liability, may be rather clearly inadequate as a standard for responsible business behavior. On other occasions, what the law requires will be uncertain. In both cases, the lawyer's sense of what is fair might provide a guide to prudent corporate behavior. Nor is the lawyer necessarily overstepping his proper role in giving forceful advice. Corporate managers, operating under time pressure and intracorporate rivalries, sometimes fail to consider the full economic and moral implications of their decisions. ${ }^{46}$ Sometimes they miscalculate the risks entailed in corporate action or inaction, misperceive the motives or the justice-claims of actual or potential adversaries.

45. William Simon has referred to this as the "positivist" view of legal ethics. See Simon, The Ideology of Advocacy: Procedural Justice and Professional Ethics, 1978 Wis. L. REv. $30,39-42$.

46. See C. Stone, Where the Law Ends: The Social Control of Corporate BeHAVIOR (1975). 
In such cases, lawyers might speak for the "true" economic interests of the corporation, as against the perceptions of particular managers. Moreover, because corporate systems for ensuring compliance with regulatory and liability laws are always vulnerable to slippage and erosion, ${ }^{47}$ opportunities exist for lawyers to take the initiative in devising and lobbying for programs to bolster existing corporate safety, environmental protection, and antifraud mechanisms.

Indeed, a number of our respondents, despite their self-identification as primarily conduits and insurers, recalled-often with a sense of satisfaction-some instances in which they exercised and forcefully presented their own judgment, rather than merely reporting the law's opportunities and constraints. New York University Law School Dean Norman Redlich, referring to his years of practice, indicated that he frequently acted as an influential and independent counselor. He advanced three justifications for doing so:

In most instances, the individual client expected such advice .... I had a responsibility to the corporate entity which went beyond the question of what the particular officer might want . . . . If a wrong course of action was followed, all of us-lawyers and clients-would have to deal with the consequences, so why not practice some preventive legal medicine? ${ }^{48}$

But even if such an influential role is desirable and appropriate on occasion, many corporate lawyers now maintain that Dean Redlich's first justification is empirically unfounded. As several of our respondents put it: "It is not avoidance [of the influential and independent counselor role]. We just aren't called on for it," or "The clients choose the type of lawyer they want." The hypotheses discussed earlier suggest why: The market for legal services has shifted. First, corporations have come to rely more upon internal specialists and inside counsel to assess high risks and make related business judgments; they are more likely to call on outside counsel at a later stage of the problem-identification and planning process, and call on outside counsel to handle delimited, technically difficult legal missions. Second, outside lawyers less frequently have strong personal relations with relevant corporate decisionmakers through which they can keep abreast of corporate plans, raise questions, or suggest alternatives on an

47. See E. Bardach \& R. KaGAN, supra note 12, at 226-34.

48. Redlich, Should a Lawyer Cross the Murky Divide?, 31 Bus. Law. 478-79 (1975). 
ongoing basis. Third, large firm lawyers increasingly market themselves not as repositories of business and moral judgment, but as expert suppliers of legal information and as performers of complex but specifically legal tasks. As a result of these changes in the market for legal work, even when autonomous judgment is possible and desirable, the typical large firm attorney is so distanced from his clients that he may fail to recognize the opportunity to forcefully present his advice and may feel uncomfortable about doing so, or may not be asked to do so.

These "changing market" hypotheses helps explain the apparent decline in the large firm lawyers' influential-and-independent-counselor role. It does not mean, however, that such a state of affairs is socially desirable or inevitable. Although lawyers sometimes justify the type of service they provide in terms of what clients demand, ${ }^{49}$ professions traditionally have justified their privileged positions by the claim that professional standards, not merely client demands, govern their work. The professional does not simply take the task as given to him. "The client, unlike the customer, is not always right."50 This statement would seem especially true of the practice of law, where thirdparty and collective interests are significantly affected by the client's law-related decisions and directives. Hence corporate lawyers who pass up opportunities to act as influential and independent counselors, because corporate managers have not asked them to do so, would seem to be forsaking an important aspect of professionalism.

One reason for the traditional professional emphasis on autonomous standards of performance is the notorious imperfection of the market for professional services: Competition among professionals is muted, clients lack information to assess what they need, and professionals have the opportunity to create demand for "unneeded" services. Although contemporary corporations may be more sophisticated purchasers of legal services than most small businessmen and individuals, the market for

49. See, e.g., Boston Bar Ass'n, Comm. on Professional Responsibility, Op. No. 79-3, cited in Leubsdorf, Three Models of Professional Reform, 67 CoRnel. L. REv. 1021, 1031 n.73 (1982) (if client requests cursory opinion, lawyer may supply it). For a general discussion of the market approach to the organization of the legal profession, see id. at $1026-36$.

50. T.H. Marshall, The Recent History of Professionalism in Relation to Social Structure and Social Policy, in Class, Citizenship and Social Development: Essays by T.H. MarSHALL 144, 150 (1964). 
legal services still has its flaws. Corporations may buy more than they really "need," as they learn when they shift some tasks from outside firms to in-house legal departments. ${ }^{51}$ But they also may buy less than they really need when outside firms do not act as forceful, independent counselors. ${ }^{52}$ Conflicting goals and pressures may push corporate managers toward short-sighted specifcation of the objectives that outside lawyers-as-conduits are instructed to pursue. Once outside lawyers are regarded solely as technicians, they may not be consulted about all potential problems. Corporate managers, preoccupied with short-term problems, may ignore legal advice not strongly and repeatedly presented. In sum, the actual demand for legal advice may fall short of what a perfectly informed, unified, responsible, and prudent corporation would demand. The acquiescence of large firm lawyers in the lack of demand for influential and independent counsel exacerbates such market imperfections.

The growth of in-house corporate legal departments, moreover, may exert a chilling effect on those large firm lawyers who do discern a legitimate need for independent and forceful counsel, and who wish to provide it. An attorney's attempt to counteract imprudent or socially harmful corporate decisions may require him to forthrightly challenge the competence or judgment of the same inside counsel who determines which law firms will continue to get the corporation's legal work. As a former associate who moved to a corporate legal department told one of our large firm partner respondents, "I fire law firms now!" Ironically, then, the more large law firm lawyers acquiesce in client demand for technical, specialized conduit and insurer services-presumably because it has been profitable to do so-the less capable they become in providing a full measure of professional influence without something approaching heroism: They would have to step out of a legalistic role in the absence of evinced client demand, reopen channels of informal communication that have been weakened, and take an aggressive marketing stance that offers a broader range of advice and consultative services.

Can large firm lawyers' reluctance to aggressively stake out a role as influential and independent counselors be defended on

51. See Fried, supra note 30.

52. See R. Rosen, Lawyers in Corporate Decision-Making, ch. 2 (unpublished Ph.D. dissertation, University of California, Berkeley, 1984). 
the ground that this role has been adequately taken over by inside corporate law departments? Probably not entirely. Large firm lawyers sometimes argue that in-house lawyers in fact lack the requisite independence. In any event, the degree to which corporate legal departments act as influential and independent counselors undoubtedly varies from company to company. Moreover, outside counsel usually will not be well-situated to evaluate much of the advice given by inside counsel to key corporate executives. As the senior Wall Street lawyer quoted earlier said, "They [inside counsel] want no one between them and their Chairman."

To some extent, the changed corporate legal environment may serve as a substitute for the influential and independent counselor role. In the last fifteen years, corporations have become much more comprehensively and intensively regulated. Changing liability rules and litigation practices have exposed them to huge damage awards. In consequence, today's corporate lawyer, in contrast to his counterpart twenty-five years ago, often can effectively block a corporate policy that is morally questionable or financially unwise simply by referring to the possibility of hostile legal action, rather than having to refer to his own sense of justice or prudence. To the extent that the legal environment has become intolerant of any corporate action or inaction that can be construed as socially harmful, the corporate lawyer, merely by acting as a conduit who informs his client of the heightened legal risks, or as an insurer who guards against these risks, necessarily acquires a very substantial social control function. However, even if this is generally true, there remains room for judgment and maneuver within the legal and regulatory process. The public interest could still be better served if lawyers served not only as conduits and insurers, informing corporate clients of legal and regulatory risks and the probabilities of avoiding them, but also as independent counselors actively encouraging cooperation with clearly justifiable regulatory requirements, shaping constructive compromises in the case of questionable ones, and affirmatively promoting corporate measures designed to prevent actionable harms.

Are there prospects for change in the future? Today, the organization of corporate legal work, as our respondents tended to confirm, leads large firm lawyers to serve as influential and independent counselors relatively infrequently and leads them 
away from aspiring to such a practice. Yet the division of labor and professional norms are susceptible to evolution and even to deliberate change. It is conceivable that market pressures-particularly if they produce competition with expanding intracorporate legal departments-might gradually impel large law firms to expand their professional roles. Today, some inside corporate counsel seek out an active role in corporate decisionmaking: They sometimes depart from the lawyer's traditional reactive stance of waiting in the office to be consulted; they take the initiative to unearth potential legal problems in operating divisions; they suggest and implement preventive compliance programs; and they insist on being apprised of emerging corporate plans so that they can affirmatively point out potential legal problems and solutions at an early stage of the decision process. ${ }^{53}$ In the same way, it is conceivable that outside law firms, in an increasingly competitive market, would more often abandon traditional reserve. Asserting that they are offering preventive law services, firms might actively offer corporate clients-small as well as large-regular workshops on legal developments, or strive to become systematically involved in corporate communication networks. These approaches can expand opportunities to serve as influential and independent counselors. To the extent that this evolution occurs, the independent social and political significance of large law firms, and the legitimacy of their claim to many of the best minds of each generation, would be enhanced.

53. See Chayes \& Chayes, Corporate Counsel and the Elite Law Firm, 37 Stan. L. REv. 277 (1985). 
HeinOnline -- 37 Stan. L. Rev. 444 1984-1985 